\title{
IDENTIFIKASI FITOKIMIA, UJI AKTIVITAS ANTIOKSIDAN DENGAN METODE 1.1-diphenyl-2-picrylhydrazyl (DPPH), DAN TOKSISITAS DENGAN METODE Brine Shrimp Lethality Test (BSLT) DARI EKSTRAK ETANOL TANGKAI BUAH PINANG YAKI (Areca vestiaria Giseke)
}

\author{
Glorya Weroy Karundeng ${ }^{1)}$, Herny E. Simbala ${ }^{1)}$, Imam Jayanto ${ }^{1)}$ \\ ${ }^{1)}$ Program Studi Farmasi Fakultas MIPA UNSRAT Manado
}

\begin{abstract}
Pinang Yaki (Areca vestiaria Giseke) which is a kind of wild palm, is a multi-functional plant. The people of North Sulawesi empirically use this plant to cure various diseases. In a previous study that said leaves, seeds and even the seed skin of areca nut have very high antioxidant content. Because of the large amount of antioxidants contained in Pinang Yaki plants, the study wanted to examine the compound content of the stalks of this plant. This study aims to determine the phytochemical content, ability of antioxidant activity, and plant toxicity, so that later it can be used as medicine. The results of this study indicate that the ethanol extract of areca fruit stalk has flavonoids, saponins, triterpenoids which have the potential as antioxidants and have a strong Inhibition Concetration 50 (IC50) value, ie, $16.52 \mu \mathrm{g} / \mathrm{mL}$ based on the 1.1-diphenyl-2-picrylhydrazyl method (DPPH), and the level of toxicity, namely the value of Lethality Concetration 50 (LC50) of $602 \mu \mathrm{g} / \mathrm{mL}$ which was carried out by the Brine Shrimp Lethality Test (BSLT) method.
\end{abstract}

Keywords: Areca vestiaria Giseke, Antioxidants, Toxicity, DPPH, BSLT

\begin{abstract}
ABSTRAK
Pinang Yaki (Areca vestiaria Giseke) yang merupakan sejenis palem liar, merupakan tanaman yang multi fungsi. Masyarakat Sulawesi Utara secara empiris menggunakan tanaman ini untuk menyembuhkan berbagai macam penyakit. Pada penelitian yang sebelumnya mengatakan bahwa daun, biji bahkan kulit biji dari Pinang Yaki mempunyai kandungan antioksidan yang sangat tinggi. Oleh karena banyaknya kandungan antioksidan yang terkandung dalam tanaman Pinang Yaki maka peneliti ingin meneliti kandungan senyawa dari tangkai buah tanaman ini. Penelitian ini bertujuan untuk mengetahui kandungan fitokimia, kemampuan aktivitas antioksidan, dan toksisitas tanaman, agar nantinya bisa digunakan sebagai obat. Hasil penelitian ini menunjukkan bahwa ekstrak etanol tangkai buah Pinang Yaki memiliki kandungan flavonoid, saponin, triterpenoid yang berpotensi sebagai antioksidan dan memiliki nilai Inhibisi Concetration 50 (IC50) yang sangat kuat yakni, 16.52 $\mu \mathrm{g} / \mathrm{mL}$ berdasarkan pengujian dengan metode 1.1-diphenyl-2-picrylhydrazyl (DPPH), dan kadar toksisitas yakni nilai Lethality Concetration 50 (LC50) sebesar $602 \mu \mathrm{g} / \mathrm{mL}$ yang dilakukan dengan metode pengujian Brine Shrimp Lethality Test (BSLT).
\end{abstract}

Kata kunci: Pinang Yaki, Antioksidan, Toksisitas, DPPH, BSLT 


\section{PENDAHULUAN}

Antioksidan merupakan senyawa yang dapat menginaktivasi radikal bebas serta menghambat pembentukan radikal bebas baru dengan cara mendonorkan elektron dan mengikat radikal bebas. Antioksidan berperan penting dalam pencegahan penyakit kanker dan penyakit degeneratif. Secara alami antioksidan dapat diperoleh dari daun sayuran dan biji - bijian, seperti asam askorbat, vitamin $\mathrm{E}$, dan senyawa fenolik. Zat antioksidan yang berasal dari tumbuhan banyak diteliti dan dikembangkan. Secara alami, tumbuhan yang mengandung antioksidan tersebar pada berbagai bagian tumbuhan seperti akar, batang, kulit, ranting, daun, buah, bunga dan biji (Hutapea, 2005).

Pinang Yaki (Areca vestiara Giseke) yang merupakan sejenis palem liar, merupakan tanaman yang multi fungsi. Masyarakat Sulawesi Utara secara empiris menggunakan tanaman ini untuk menyembuhkan berbagai macam penyakit seperti diabetes dan diare. Selain itu juga dipakai sebagai obat kontrasepsi dan anti tumor/anti kanker. Berdasarkan penelitian sebelumnya mengenai tanaman Pinang Yaki, buah, biji, bahkan kulit biji dari tanaman ini diketahui mengandung senyawa metabolit sekunder yaitu flavonoid, triterpenoid, tanin, dan saponin (Simbala, 2006). Oleh karena banyaknya kandungan senyawa yang terkandung dalam tanaman Pinang Yaki seperti pada buah, biji, bahkan kulit biji dari tanaman ini maka kali ini peneliti ingin meneliti kandungan senyawa tangkai buah dari tanaman Pinang Yaki. Dalam penelitian ini dilakukan identifikasi fitokimia untuk mengetahui senyawa metabolit sekunder yang terdapat dalam tangkai buah Pinang Yaki serta uji aktivitas antioksidan dengan metode 1,1-diphenyl - 2 - picrylhydrazyl (DPPH) untuk mengetahui kemampuan ekstrak dalam menghambat radikal bebas dan Uji toksisitas (Simbala, 2006).

Untuk mengidentifikasi senyawa antioksidan dapat menggunakan senyawa 1.1-diphenyl-2-picrylhydrazyl (DPPH). Senyawa radikal kromogen seperti DPPH dapat secara langsung bereaksi dengan antioksidan. DPPH digunakan untuk mengevaluasi kemampuan antioksidan dari komponen dengan mengukur perubahan absorbansi, absorbansi DPPH akan menurun apabila elektron ganjil dari atom hidrogen dalam DPPH direduksi dengan penerimaan sebuah atom hidrogen dari antioksidan. Pengukuran aktivitas antioksidan dapat diketahui berdasarkan nilai Inhibisi Concetration (IC) 50, dimana menunjukkan kemampuan senyawa menghambat proses oksidasi sebesar 50\% (Molyneux, 2004).

Uji toksisitas merupakan uji pendahuluan yang dilakukan untuk mengetahui efek toksik dan ambang batas penggunaan suatu tumbuhan sebagai obat. Uji toksisitas dapat dilakukan dengan menggunakan metode Brine Shrimp Lethality Test (BSLT) terhadap larva Artemia salina Leach. BSLT merupakan metode untuk mengetahui tingkat toksisitas suatu senyawa aktif terhadap larva udang Artemia salina. Senyawa aktif yang memiliki daya toksisitas tinggi diketahui berdasarkan nilai Lethal Concetration $50 \%\left(\mathrm{LC}_{50}\right)$. Nilai $\mathrm{LC}_{50}$ yaitu suatu nilai yang menunjukkan konsentrasi zat toksik yang menyebabkan kematian hewan uji sebesar 50\%. Hasil uji toksisitas dapat dijadikan tolak ukur penggunaan konsentrasi senyawa aktif yang aman untuk digunakan sebagai obat. 


\section{METODOLOGI PENELITIAN}

Alat yang digunakan dalam penelitian yakni blender, ayakan, kertas saring whatman 42, tabung reaksi, rak tabung, cawan petri, labu takar, mikroppet, pipet tetes, baker glass, timbangan analitik, gelas ukur, erlenmeyer, incubator, batang pengaduk, alumunium foil, orbital shaker, spektrofotometer uv-vis, spatula, corong.

Bahan yang digunakan dalam penelitian ini yaitu tangkai buah Pinang Yaki (Areca vestiaria). Bahan kimia yang digunakan Etanol 96\%, metanol pro analisis, vitamin C p.a, Air laut, Naupilus Artemia salina, Aquadest, DPPH, $\mathrm{HCl}$ pekat, $\mathrm{NaOH}, \mathrm{FeC}_{13}$, Serbuk Magnesium.

\section{PENGAMBILAN DAN PERSIAPAN SAMPEL}

Sampel yang digunakan pada penelitian ini yaitu tangkai buah dari Pinang Yaki (Areca vestiaria) yang diambil di Desa Tanggari Kec. Airmadidi, Sulawesi Utara. Sampel kemudian dicuci untuk menghilangkan sisa kotoran yang dapat mengganggu dan dikeringkan sampai kering. Selanjutnya sampel ditimbang berat basah kemudian dihaluskan menggunakan blender hingga sampel menjadi halus lalu diayak dengan ayakan.

\section{IDENTIFIKASI TANAMAN}

Identifikasi tanaman dilakukan di Bagian Taksonomi Tumbuhan Program Studi Biologi Fakultas Matematika dan Ilmu Pengetahuan Alam, Universitas Sam Ratulangi Manado.

\section{EKSTRAKSI SAMPEL}

Sampel yang digunakan pada penelitian ini yaitu tangkai buah dari Pinang Yaki (Areca vestiaria) yang diambil di Desa Tanggari Kec. Airmadidi, Sulawesi Utara. Sampel kemudian dicuci untuk menghilangkan sisa kotoran yang dapat mengganggu dan dikeringkan sampai kering. Selanjutnya sampel ditimbang berat basah kemudian dihaluskan menggunakan blender hingga sampel menjadi halus lalu diayak dengan ayakan.

\section{UJI FITOKIMIA}

Uji fitokimia merupakan uji kualitatif untuk mengetahui keberadaan senyawa metabolit sekunder yang terkandung dalam ekstrak tangkai buah Piang Yaki. Identifikasi yang dilakukan adalah identifikasi flavonoid, saponin, triterpenoid, dan tanin.

\section{IDENTIFIKASI FLAVONOID}

Sebanyak 0.5 gram ekstrak ditambahkan $2 \mathrm{~mL}$ etanol 96\%, kemudian dipanaskan dalam penangas air sampai mendidih. Dipipet lapisan yang atas kemudian ditambahkan 2-3 tetes HCL pekat dan 0.1 gram serbuk $\mathrm{Mg}$. Selanjutnya diamkan selama 3 menit, bila terjadi perubahan warna menjadi merah atau kekuning-kuningan berarti menunjukkan adanya flavonoid.

\section{IDENTIFIKASI SAPONIN}

Sebanyak 0.5 gram ekstrak ditambahkan $5 \mathrm{~mL}$ aquades sambil dikocok kuat selama 1 menit. Pada tabung sampel terdapat buih setinggi $3.5 \mathrm{~cm}$ dan bila busa yang terbentuk tetap stabil \pm 7 menit, berarti menunjukanadanya banyak saponin.

\section{IDENTIFIKASI TRITERPENOID}

Sebanyak 0.5 gram ekstrak ditambahkan $\mathrm{CH} 3 \mathrm{COOH}$ glacial sebanyak 
10 tetes dan $\mathrm{H} 2 \mathrm{SO} 4$ pekat sebanyak 2 tetes. Larutan kemudian dikocok perlahan dan dibiarkan selama beberapa menit. Steroid memberikan warna biru atau hijau, sedangkan triterpenoid memberikan warna merah atau ungu.

\section{IDENTIFIKASI TANIN}

Sebanyak 0.5 gram ekstrak ditambahkan etanol 96\%. Kemudian didiamkan \pm 15 menit, lalu disaring. Filtrat yang didapat dipipet dan ditambahkan 2 tetes NaCL $10 \%$ dan 3 tetes FeCL3 1\%. Terbentuknya warna biru/hitam kehijauan menunjukkan adanya tannin (Sangi et al., 2008).

\section{UJI AKTIVITAS ANTIOKSIDAN DENGAN METODE DPPH}

Pengujian aktivitas antioksidan ekstrak tangkai buah Pinang Yaki ini menggunakan radikal bebas 1.1-diphenyl2-picrylhydrazyl (DPPH) seperti yang dilakukan oleh Molyneux (2004). Konsentrasi ekstrak Pinang Yaki yang digunakan adalah $10 \mu \mathrm{g} / \mathrm{ml}, 8 \mu \mathrm{g} / \mathrm{ml}, 6$ $\mu \mathrm{g} / \mathrm{ml}, \quad 4 \mu \mathrm{g} / \mathrm{ml}$, dan $2 \mu \mathrm{g} / \mathrm{ml}$. Untuk pembuatan larutan stok diambil $10 \mathrm{mg}$ ekstrak dan dimasukkan ke dalam $10 \mathrm{~mL}$ pelarutnya, hingga diperoleh konsentrasi larutan stok $1000 \mu \mathrm{g} / \mathrm{ml}$.

a. Untuk konsentrasi $10 \mu \mathrm{g} / \mathrm{ml}$ dibuat dengan cara diambil $0,1 \mathrm{~mL}$ larutan stok dan dimasukkan ke dalam 9,9 mL pelarutnya.

b. Untuk konsentrasi $8 \mu \mathrm{g} / \mathrm{ml}$ dibuat dengan cara diambil $0,08 \mathrm{~mL}$ larutan stok dan dimasukkan ke dalam 9,92 mL pelarutnya.

c. Untuk konsentrasi $6 \mu \mathrm{g} / \mathrm{ml}$ dibuat dengan cara diambil $0,06 \mathrm{~mL}$ larutan stok dan dimasukkan ke dalam 9,94 mL pelarutnya. d. Untuk konsentrasi $4 \mu \mathrm{g} / \mathrm{ml}$ dibuat dengan cara diambil $0,04 \mathrm{~mL}$ larutan stok dan dimasukkan ke dalam 9,96 mL pelarutnya.

e. Untuk konsentrasi $2 \mu \mathrm{g} / \mathrm{ml}$ dibuat dengan cara diambil $0,02 \mathrm{~mL}$ larutan stok dan dimasukkan ke dalam 9,98 mL pelarutnya.

Larutan DPPH 0,4 $\mathrm{mM}$ dibuat dengan cara ditimbang 7,88 mg DPPH (BM 394,32 g/mol) dilarutkan dengan metanol p.a hingga $50,0 \mathrm{~mL}$ dalam labu takar 50 mL. Kedalam tiap tabung reaksi ditambahkan $1 \mathrm{~mL}$ larutan DPPH 0,4 mM dalam metanol. Masing-masing konsentrasi sampel dimasukkan kedalam tabung reaksi, volume dicukupkan sampai $5 \mathrm{~mL}$, kemudian diinkubasi pada suhu $27^{\circ} \mathrm{C}$ selama 30 menit. Hal ini dilakukan untuk mengoptimumkan aktivitas DPPH agar terjadi reaksi antara DPPH dengan sampel yang diuji. Selanjutnya serapan diukur dengan spektrofotometer UV-Vis pada panjang gerombang $517 \mathrm{~nm}$. Vitamin C p.a digunakan sebagai pembanding dengan konsentrasi $2 \mu \mathrm{g} / \mathrm{mL}, 4 \mu \mathrm{g} / \mathrm{mL}, 6$ $\mu \mathrm{g} / \mathrm{mL}, 8 \mu \mathrm{g} / \mathrm{mL}, 10 \mu \mathrm{g} / \mathrm{mL}$.

\section{ANALISIS DATA ( PENENTUAN NILAI IC 50 (Inhibitory Concentration)}

Kemampuan untuk meredam radikal bebas DPPH, Parameter yang bisa digunakan untuk menginterprestasikan hasil dari uji aktivitas antioksidan dengan metode DPPH adalah dengan nilai $\mathrm{IC}_{50}$, yaitu konsentrasi yang menyebabkan hilangnya 50\% aktivitas DPPH. Untuk menghitung nilai $\mathrm{IC}_{50}$ diperlukan data persen inhibisi dari pengujian yang dilakukan. Persen inhibisi dapat dihitung dengan menggunakan rumus sebagai berikut:

$\%$ inhibisi $=\frac{\text { absorbansi blanko-absorbansi sampel }}{\text { absorbansi blanko }} \times 100 \%$ 


\section{UJI TOKSISITAS DENGAN METODE} BSLT

Pengujian toksisitas ekstrak tangkai buah Pinang Yaki menggunakan metode Brine Shrimp Lethality Test (BSLT) yang mengacu pada Krishnaraju et al. (2005) dengan cara mengujikan senyawa yang diduga toksik terhadap larva A. salina.

\section{PERSIAPAN LARVA Artemia salina L.}

Penetasan telur Artemia salina dilakukan dengan cara merendam sebanyak $50 \mathrm{mg}$ telur Artemia salina dalam wadah yang berisi air laut dibawah cahaya lampu 25 watt. Telur Artemia salina akan menetas dan menjadi larva setelah 24 jam. Larva Artemia salina yang baik digunakan untuk uji BSLT yaitu yang berumur 48 jam sebab jika lebih dari 48 jam dikhawatirkan kematian Artemia salina bukan disebabkan toksisitas melainkan oleh terbatasnya persediaan makanan (Pamolango, 2016).

\section{PEMBUATAN KONSENTRASI SAMPEL UJI}

Pembuatan konsentrasi larutan uji untuk BSLT adalah $1000 \mu \mathrm{g} / \mathrm{mL}, 100$ $\mu \mathrm{g} / \mathrm{mL}, 10 \mu \mathrm{g} / \mathrm{mL}, 1 \mu \mathrm{g} / \mathrm{mL}$, dan larutan kontrol negatif sesuai metode yang dipakai oleh Surya (2018).

a. Masing-masing ekstrak etanol 96\% tangkai buah Pinang Yaki (Areca vestiaria) ditimbang sebanyak $50 \mathrm{mg}$, kemudian dilarutkan dengan air laut sebanyak $50 \mathrm{~mL}$ untuk memperoleh konsentrasi $1000 \mu \mathrm{g} / \mathrm{mL}$.

b. Dari larutan dengan konsentrasi 1000 $\mu \mathrm{g} / \mathrm{mL}$ diambil $5 \mathrm{~mL}$ dan dilarutkan dengan air laut hingga $50 \mathrm{~mL}$ untuk mendapatkan konsentrasi $100 \mu \mathrm{g} / \mathrm{mL}$.

c. Dari larutan dengan konsentrasi 100 $\mu \mathrm{g} / \mathrm{mL}$ diambil $5 \mathrm{~mL}$ dan dilarutkan dengan air laut hingga $50 \mathrm{~mL}$ untuk mendapatkan konsentrasi $10 \mu \mathrm{g} / \mathrm{mL}$.

d. Dari larutan dengan konsentrasi 10 $\mu \mathrm{g} / \mathrm{mL}$ diambil $5 \mathrm{~mL}$ dan dilarutkan dengan air laut hingga $50 \mathrm{~mL}$ untuk mendapatkan konsentrasi $1 \mu \mathrm{g} / \mathrm{mL}$.

e. Untuk mendapatkan larutan control negatif dibuat dengan mengambil 10 $\mathrm{mL}$ air laut.

\section{PELAKSANAAN UJI TOKSISITAS}

Pada setiap konsentrasi dari ekstrak etanol 96\% tangkai Pinang Yaki dilakukan Uji Toksisitas dengan 3 replikasi menggunakan 10 ekor larva pada setiap kelompok uji. Sebanyak 3 replikasi digunakan untuk konsentrasi $100 \mu \mathrm{g} / \mathrm{mL}, 3$ replikasi untuk konsentrasi $10 \mu \mathrm{g} / \mathrm{mL}, 3$ replikasi untuk konsentrasi $1 \mu \mathrm{g} / \mathrm{mL}$, dan 3 replikasi untuk sebagai kontrol negatif. Pengamatan dilakukan selama 24 jam terhadap kematian larva A. salina. Kriteria standar untuk menilai kematian larva A. salina yaitu bila larva A. salina tidak menunjukkan pergerakkan selama beberapa detik observasi (Krishnaraju et al., 2005).

\section{ANALISIS DATA}

Data hasil penelitian akan diolah dalam bentuk tabel dan grafik. Data akan dianalisis dengan analisis regresi linier menggunakan aplikasi perhitungan Microsoft Excel 2013 untuk memastikan nilai $\mathrm{IC}_{50}$ dan $\mathrm{LC}_{50}$.

\section{HASIL DAN PEMBAHASAN PENYIAPAN SIMPLISIA}

Bagian tanaman yang digunakan yakni tangkai buah dari Pinang Yaki (Areca vestiaria) yang diambil di Desa Tanggari Kec. Airmadidi, Sulawesi Utara. Sampel dicuci dengan air dan dikeringkan 
kemudian diserbuk menggunakan alat blender dan diayak dengan ayakan. Proses pencucian sampel yang dilakukan bertujuan untuk memisahkan kotorankotoran atau bahan asing lainnya yang menempel pada sampel. Proses pengeringan sampel bertujuan untuk menghilangkan kadar air dalam sampel karena selain dapat mengganggu proses penarikan zat aktif, kadar air yang tinggi juga dapat membuat sampel mudah rusak oleh adanya pertumbuhan jamur. Proses penyerbukkan sampel bertujuan untuk memperbesar luas permukaan kontak dengan pelarut sehingga mengoptimalkan proses ekstraksi. Proses pengayakan bertujuan untuk menyeragamkan ukuran partikel, dimana keseragaman ukuran partikel ini dapat mempengaruhi keseragaman tahapan ekstraksi (Saifuddin et al, 2011).

\section{EKSTRAKSI}

Proses ekstraksi serbuk tangkai buah Pinang Yaki diekstraksi menggunakan metode maserasi dengan sistem remaserasi atau maserasi berulang. Serbuk tangkai buah yang digunakan sebesar 200 gram direndam menggunakan etanol 96\% kemudian dimasukkan ke dalam Erlenmeyer dan digojok menggunakan alat orbital shaker dengan pengadukan selama 24 jam dengan kecepatan 150 rpm. Pemilihan metode maserasi dikarenakan maserasi adalah metode pemisahan senyawa dengan cara perendaman menggunakan pelarut organik pada temperatur ruangan. Proses maserasi sangat menguntungkan dalam isolasi senyawa bahan alam karena selain murah dan mudah dilakukan, dengan perendaman sampel tumbuhan akan terjadi pemecahan dinding dan membran sel akibat perbedaan tekanan antara di dalam dan di luar sel, sehingga senyawa metabolit sekunder yang ada di dalam sitoplasma akan terlarut dalam pelarut (Pamolango, 2016). Tahap remaserasi bertujuan untuk mendapatkan hasil ekstrak yang banyak dimana seluruh zat aktif akan tersari sempurna. Penggantian pelarut dengan yang baru setiap kali proses remaserasi akan menghindari terjadinya kejenuhan dalam proses penyarian (Edy, 2016).

\section{IDENTIFIKASI FITOKIMIA}

Identifikasi fitokimia bertujuan untuk mengetahui kandungan golongan senyawa sebagai suatu tumbuhan sebagai informasi awal untuk meramalkan aktivitas biologi suatu tanaman. Pada penelitian ini dilakukan identifikasi fitokimia untuk menguji ada tidaknya golongan senyawa yang berpotensi sebagai antioksidan dan berpotensi toksik, yaitu golongan flavonoid, tanin, saponin, dan triterpenoid. Hasil penujian fitokimia dapat dilihat pada Tabel 1.

Tabel 1. Hasil Identifikasi fitokimia.

\begin{tabular}{llc}
\hline $\begin{array}{c}\text { Senyawa } \\
\text { Metabolit }\end{array}$ & $\begin{array}{c}\text { Perubahan } \\
\text { Positif }\end{array}$ & $\begin{array}{c}\text { Perubahan } \\
\text { yang } \\
\text { terjadi }\end{array}$ \\
\hline Flavonoid & $\begin{array}{l}\text { Warna } \\
\text { merah, } \\
\text { kuning, } \\
\text { atau jingga }\end{array}$ & + \\
Saponin & $\begin{array}{l}\text { Busa stabil } \\
\text { setinggi 1- }\end{array}$ & + \\
& 10 cm & \\
Triterpen & $\begin{array}{l}\text { Cincin } \\
\text { kecoklatan } \\
\text { atau violet }\end{array}$ & + \\
& Warna \\
Tanin & hitam \\
& kebiruan \\
& atau hijau & - \\
\hline
\end{tabular}




\section{UJI AKTIVITAS ANTIOKSIDAN DENGAN METODE DPPH}

Pengujian aktivitas antioksidan pada ekstrak etanol tangkai buah Pinang Yaki dilakukan dengan menggunakan metode DPPH dengan panjang gelombang 517nm. Menurut Molyneux (2004), penggunaan metode DPPH merupakan cara pengujian yang cepat, mudah, dan peka serta hanya memerlukan sedikit sampel untuk evaluasi aktivitas antioksidan dari senyawa bahan alam. Hasil pengujian DPPH dapat dilihat pada Tabel 2.

Tabel 2. Perbandingan Aktivitas

Antioksidan

\begin{tabular}{cc}
\hline Sampel & IC $_{\mathbf{5 0}}(\boldsymbol{\mu g} / \mathbf{m L})$ \\
\hline $\begin{array}{c}\text { Ekstrak Etanol } \\
\text { Tangkai Buah Pinang } \\
\text { Yaki } \\
\text { Vitamin C p.a }\end{array}$ & 16.52 \\
\hline
\end{tabular}

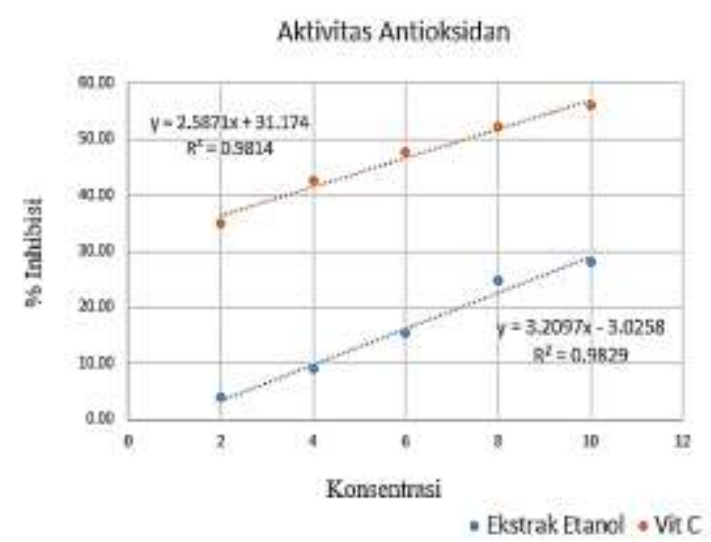

Gambar 1. Grafik Aktivitas Antioksidan

Berdasarkan hasil yang diperoleh pada pengujian DPPH persen inhibisi pada ekstrak etanol tangkai buah Pinang Yaki mengalami peningkatan pada konsentrasi tertinggi yaitu $10 \mu \mathrm{g} / \mathrm{mL}$ yakni $28,13 \%$. Peningkatan persen inhibisi ini pada ekstrak menandakan bahwa semakin besar konsentrasi ekstrak maka semakin besar persen inhibisi. Hal ini didukung oleh penelitian yang dilakukan oleh Hanani et al., (2005) yang menyatakan bahwa presentase penghambatan (persen inhibisi) terhadap aktivitas radikal bebas akan ikut meningkat seiring dengan meningkatnya konsentrasi.

Berdasarkan perubahan warna yang terjadi dapat diketahui bahwa ekstrak memiliki aktivitas antioksidan yang sangat kuat, hal ini ditunjukan dengan warna yang berubah pada larutan dari ungu menjadi kuning pucat. Adanya perubahan yang terjadi disebabkan ketika larutan DPPH dicampur dengan suatu senyawa yang dapat mendonasikan atom hidrogen, maka DPPH berubah menjadi bentuk tereduksi (1,1-difenil-2-pikrihidrazin) dengan kehilangan warna violet menjadi warna kuning. Perubahan warna kuning ini menghasilkan senyawa bukan radikal $(1,1$ difenil-2-pikrihidrazin) dan radikal (A.) (Suryanto, 2012).

Kemampuan aktivitas penangkal radikal bebas eksrtrak tangkai buah Pinang Yaki ini dibuktikan dengan nilai $\mathrm{IC}_{50}$ yang sangat kuat sebesar $16.52 \mu \mathrm{g} / \mathrm{mL}$, Nilai ini didapat dengan menghitung persamaan linear dari Gambar 1. Flavonoid merupakan senyawa penyebab adanya antioksidan. Senyawa flavonoid memiliki potensi sebagai antioksidan karena memiliki gugus hidroksil yang terikat pada karbon cincin aromatik sehigga dapat menangkap radikal bebas yang dihasilkan dari reaksi peroksidasi lemak. Senyawa flavonoid akan menyumbangkan satu atom hidrogen untuk menstabilkan radikal peroksi lemak (Dewi, 2014).

Pembanding yang digunakan dalam penelitian ini yaitu vitamin $\mathrm{C}$ p.a dengan konsentrasi yaitu $2 \mu \mathrm{g} / \mathrm{mL}, 4 \mu \mathrm{g} / \mathrm{mL}, 6$ 
$\mu \mathrm{g} / \mathrm{mL}, 8 \mu \mathrm{g} / \mathrm{mL}, 10 \mu \mathrm{g} / \mathrm{mL}$. Nilai $\mathrm{IC}_{50}$ dari Vitamin $\mathrm{C}$ didapat sebesar 7.28 $\mu \mathrm{g} / \mathrm{mL}$, nilai ini menunjukkan bahwa kemampuan penangkal radikal bebas dari Vitamin C lebih kuat dibandingkan dengan ekstrak etanol tangkai buah Pinang Yaki. Vitamin $\mathrm{C}$ memiliki aktivitas antioksidan yang tinggi karena vitamin $\mathrm{C}$ memiliki 2 gugus hidroksil yang mengakibatkan lebih mudah dalam pendonoran hidrogen (Blois, 2005).

Menurut Molyneux (2004), suatu antioksidan dikatakan sebagai antioksidan dengan aktivitas sangat kuat ketika nilai IC50 kurang dari $50 \mu \mathrm{g} / \mathrm{mL}$ (IC50< 50 $\mu \mathrm{g} / \mathrm{mL})$, kuat $(50 \mu \mathrm{g} / \mathrm{mL}<$ IC50< 100 $\mu \mathrm{g} / \mathrm{mL})$, sedang $(100 \mu \mathrm{g} / \mathrm{mL}<$ IC $50<150$ $\mu \mathrm{g} / \mathrm{mL})$, lemah $(150 \mu \mathrm{g} / \mathrm{mL}<$ IC50< 200 $\mu \mathrm{g} / \mathrm{mL}$ ), dan sangat lemah (IC50> 200 $\mu \mathrm{g} / \mathrm{mL})$. Hal ini menunjukan bahwa vitamin $\mathrm{C}$ dan ektrak etanol tangkai buah Pinang Yaki merupakan antioksidan dengan aktivitas sangat kuat.

Tabel 3. Presentase Jumlah Kematian Larva kematian larva udang disebabkan oleh peningkatan konsentrasi dalam sampel. Pada kontrol negatif tidak terjadi kematian, sehingga dapat dikatakan bahwa kematian larva bukan dikarenakan pengaruh air laut, melainkan karena ekstrak yang diberikan.

Hasil pengujian tersebut memberikan nilai

\section{PENGUJIAN TOKSISITAS DENGAN METODE BSLT}

Pengujian aktivitas toksisitas yang dilakukan dengan metode BSLT menggunakan larva udang Artemia salina. Kemampuan toksisitas ekstrak etanol dari tangkai buah Pinang Yaki dalam mematikan larva udang yang telah diberi perlakuan dengan konsentrasi 1, 10, 100 dan $1000 \mathrm{mg} / \mathrm{L}$ dapat dilihat dalam tabel 3 .

Berdasarkan Tabel 3 dapat dilihat bahwa semakin tinggi konsentrasi maka semakin besar juga tingkat kematian larva, dimana tingkat kematian tertinggi terdapat pada konsentrasi $1000 \mu \mathrm{g} / \mathrm{mL}$ dan kematian terendah pada konsentrasi 1 $\mu \mathrm{g} / \mathrm{mL}$.

\begin{tabular}{|c|c|c|c|c|c|}
\hline \multirow[b]{2}{*}{ Pengujian } & \multirow[b]{2}{*}{$\begin{array}{c}\text { Kontrol (-) } \\
0 \mu \mathrm{g} / \mathrm{mL}\end{array}$} & \multicolumn{4}{|c|}{ Jumlah Kematian Setiap Konsentrasi } \\
\hline & & $\begin{array}{c}1 \\
\mu \mathrm{g} / \mathrm{mL}\end{array}$ & $\begin{array}{c}10 \\
\mu \mathrm{g} / \mathrm{mL}\end{array}$ & $\begin{array}{c}100 \\
\mu \mathrm{g} / \mathrm{mL}\end{array}$ & $1000 \mu \mathrm{g} / \mathrm{mL}$ \\
\hline 1 & 0 & 0 & 2 & 4 & 6 \\
\hline 2 & 0 & 0 & 1 & 3 & 6 \\
\hline 3 & 0 & 0 & 1 & 2 & 5 \\
\hline
\end{tabular}

\begin{tabular}{cccccc} 
Total Kematian & 0 & 0 & 4 & 9 & 17 \\
\hline Rata-rata & 0 & 0 & 1.3 & 3 & 5.6 \\
\hline $\begin{array}{c}\text { Persentase } \\
\text { Kematian }\end{array}$ & $0 \%$ & $0 \%$ & $13 \%$ & $30 \%$ & $56 \%$ \\
\hline
\end{tabular}

Menurut Apu (2013) Tingkat kematian dapat ditemukan secara langsung melalui perbandingan konsentrasi yang berkisar dari konsentrasi terendah hingga konsentrasi tertinggi. Dengan kata lain,
LC $_{50}$ sebesar $602 \mu \mathrm{g} / \mathrm{mL}$ yang dihitung menggunakan analisis probit. 
Tabel 4. Nilai Probit

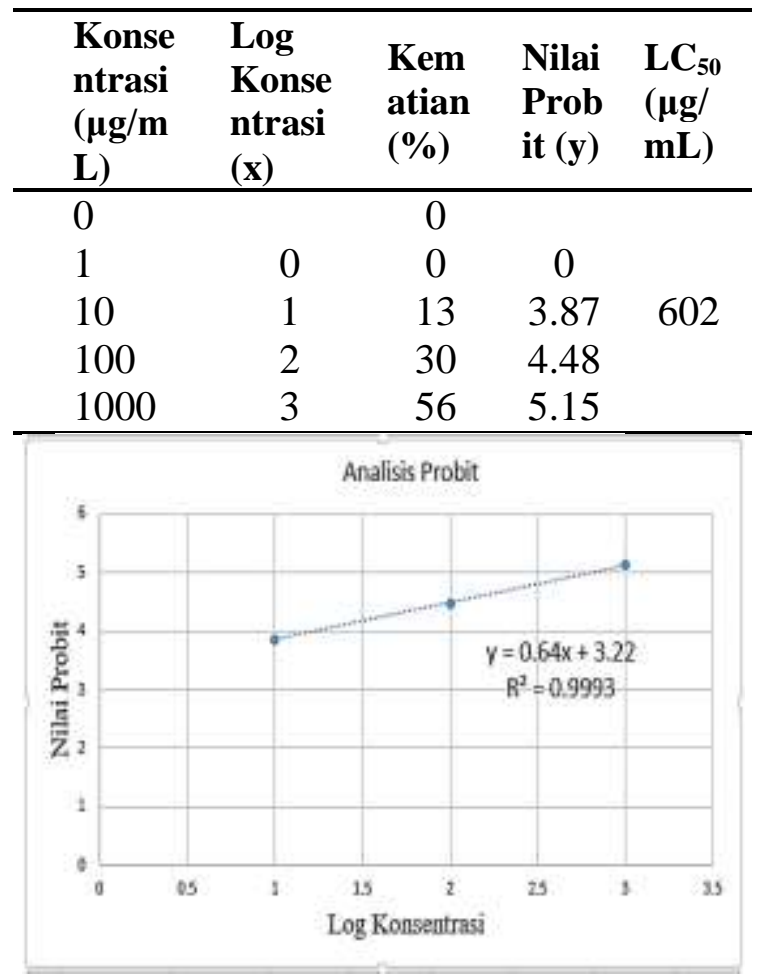

Gambar 2. Grafik Analisis Probit

Suatu ekstrak dapat disebut toksik apabila mempunyai nilai $\mathrm{LC}_{50}<1000$ $\mathrm{mg} / \mathrm{L} . \mathrm{LC}_{50}$ yaitu konsentrasi yang dapat mematikan $50 \%$ larva udang laut. Hasil analisis probit pada gambar 2 menggunakan persamaan regresi linear yang menunjukkan bahwa nilai $\mathrm{LC}_{50}$ dari ekstrak etanol tangkai buah piang yaki yakni $602 \mu \mathrm{g} / \mathrm{mL}$. Hal ini menunjukkan bahwa ekstrak etanol tangkai buah Pinang Yaki bersifat toksik.

Kematian larva A. salina disebabkan karena keberadaan senyawa metabolit sekunder yang bersifat toksik. Triterpenoid merupakan senyawa penyebab adanya sifat toksik. Berdasarkan identifikasi fitokimia yang dilakukan didapati ekstrak etanol positif mengandung triterpenoid. Ketika senyawa tersebut tertelan oleh larva, maka akan menyebabkan efek antifeedant yang membuat larva A. salina tidak bisa makan, sehingga menyebabkan larva mati. Kemampuan suatu ekstrak menyebabkan kematian larva melalui mekanisme stomach poisoning dimana larva mengalami gangguan pada saluran cernanya serta reseptor permukaan mulut larva dihambat sehingga larva tidak bisa mendeteksi makanan sehingga mati kelaparan (Julfitriyani, 2016).

\section{KESIMPULAN}

Berdasarkan hasil penelitian yang telah dilakukan dapat disimpulkan bahwa ekstrak etanol tangkai buah Pinang Yaki (Areca vestiaria) memiliki senyawa metabolit sekunder yaitu Flavonoid, Saponin, dan Triterpenoid. Ekstrak etanol tangkai buah Pinang Yaki (Areca vestiaria) memiliki aktivitas antioksidan sangat kuat dengan nilai $\mathrm{IC}_{50}$ sebesar 16.52 $\mu \mathrm{g} / \mathrm{mL}$. Dan ekstrak etanol tangkai buah Pinang Yaki (Areca vestiaria) memiliki sifat toksik dengan nilai $\mathrm{LC}_{50}$ sebesar 602 $\mu \mathrm{g} / \mathrm{mL}$.

\section{SARAN}

Dari hasil penelitian ini perlu dilakukannya penelitian lebih lanjut mengenai khasiat dari tangkai buah Pinang Yaki (Areca vestiaria) karena memiliki aktifitas antioksidan yang sangat kuat dan bersifat toksik yang bisa berpotensi sebagai bahan obat.

\section{DAFTAR PUSTAKA}

Dewi, A. C., N. M. Puspawati., I. M. D. Swantara., A. Asih., W. S. Rita. 2014. Aktivitas Antioksidan Senyawa Flavonoid Ekstrak Etanol Biji Terong Belanda (Solanum betaceum, syn) Dalam Menghambat Reaksi Peroksidasi Lemak Pada Plasma Darah Tikus 
PHARMACON- PROGRAM STUDI FARMASI, FMIPA, UNIVERSITAS SAM RATULANGI, Volume 8 Nomor 3 Agustus 2019

Wistar. Jurnal Cakra Kimia. 2:(4) 7- 16

Edy, H. J., Marchaban, S. Wahyuono, A. E. Nugroho. 2016. Formulasi dan Uji Sterilitas Hidrogel Herbal Ekstrak Etanol Daun Tagetes erecta L. Pharmacon. 5(2) 9-16.

Hernani, R. M. 2005. Tanaman Berkhasiat Antioksidan, Jakarta: Penebar Swadya.

Hutapea, R. 2005. Sehat dan Ceria Diusia Senja. Jakarta: Rineka Cipta.

Julfitriyani, M. R. J. Runtuwene,. D. Wewengkang. 2016. Uji Aktivitas Antioksidan Dan Toksisitas Ekstrak Etanol Daun Foki Sabarati (Solanum Torvum). Pharmacon. 5(3) 94-101

Krishnaraju A. V., Rao., Sundraraju, A. 2005. Assestment of Biooctivity of Indian Medical Plants tlsing Brine Shrimp (Artemia salina) Lethality Assay.lnternational Journal Applied Science and Engineering.(2): 125-134.

Molyneux, P. 2004. The Use of The Stable Free Radical diphenylpicrylhydrazyl (DPPH) for Estimating Antioxidant Activity, Songklanakarin: Journal Science Technology, 26:(2) 211-219.

Pamolango, S. A., W. Bodhi., A. C. Wullur. 2016. Uji Fitokimia, Antioksidan, Dan Toksisitas Dari Ekstrak Daun Kentang (Solanum tuberosum) Dengan Metode 1.1- diphenyl-2-picrylhydrazyl (DPPH) dan Brine Shrimp Lethality Test (BSLT). Pharmacon. 5:(3) 75-84.

Saifudin, A., Rahayu, V., Teruna, H. Y. 2011. Standardisasi Bahan Obat Alam. Graha Ilmu: Jakarta.

Sangi, M., Runtuwene, M. R. J., Simbala, H. E. I., Makang, V. M. A. 2008. Analisis Fitokimia Tumbuhan Obat di Kabupaten Minahasa Utara. Chemistry Progress. 1(1).

Simbala, H.E.I. 2006. Keanekaragaman Floristik dan Pemanfaatannya sebagai Tumbuhan Obat di Kawasan Konservasi II Taman Nasional Bogani Nani Wartabone (Kabupaten Bolaang Mongondow Sulawesi Utara). Disertasi. Institut Pertanian Bogor, Bogor.

Surya, A. 2018.Toksisitas Ekstrak Metanol Kulit Jengkol (Pithecellobium Jiringa) dengan Metode Brine Shrimp LethalityTest terhadap Larva Udang (Artemia salina),Jurnal Rekayasa Sistem Industri. 3:(2)149-153.

Suryanto, E. 2012. Fitokimia Antioksidan, Surabaya; Putra Media Nusantara. 